\begin{tabular}{|l|l|l||}
\hline \multicolumn{2}{|c|}{ PublisherInfo } \\
\hline \hline PublisherName & $:$ & BioMed Central \\
\hline \hline PublisherLocation & $:$ & London \\
\hline \hline PublisherImprintName & $:$ & BioMed Central \\
\hline \hline
\end{tabular}

\title{
IL-10 promotes wirway hyperresponsiveness
}

\begin{tabular}{|c|c|c|}
\hline \multicolumn{3}{|c|}{ ArticleInfo } \\
\hline ArticleID & : & 1624 \\
\hline ArticleDOI & : & 10.1186/rr-2001-68543 \\
\hline ArticleCitationID & : & 68543 \\
\hline ArticleSequenceNumber & : & 35 \\
\hline ArticleCategory & : & Paper Report \\
\hline ArticleFirstPage & : & 1 \\
\hline ArticleLastPage & : & 3 \\
\hline ArticleHistory & : & $\begin{array}{ll}\text { RegistrationDate } & : 2001-9-18 \\
\text { Received } & : 2001-2-21 \\
\text { OnlineDate } & : 2001-9-18\end{array}$ \\
\hline ArticleCopyright & : & Biomed Central Ltd2001 \\
\hline ArticleGrants & : & \\
\hline ArticleContext & : & 129312211 \\
\hline
\end{tabular}


Kristen page, Aff1

Corresponding Affiliation: Aff1

Aff1 The University of Chicago, IL, USA

\section{Keywords}

Asthma, bronchial hyperresponsiveness, eosinophilia, interleukin-10

\section{Context}

Interleukin (IL)-10, a Th2 cytokine, is increased in bronchoalveolar lavage fluid following allergen challenge, and is thought to downregulate allergic inflammation. Development of airway hyperresponsiveness (AHR) in models of asthma is thought to depend on Th2-mediated inflammation, specifically inflammation bought about by increases in IL-4, IL-5, eosinophils, and Th2 lymphocytes. The aim of this study was to compare the development of AHR in wild-type and IL-10-deficient mice in response to ragweed allergen challenge.

\section{Significant findings}

Allergen challenge increased AHR in wild type, but not IL-10-knockout (KO), mice. Airway constriction, measured as a marker of AHR development, also increased in wild-type but not IL-10-KO mice. Administration of recombinant IL-10 increased AHR in IL-10-KO mice. AHR was detected in severe combined immunodeficient (SCID) mice receiving mononuclear splenocytes from wild-type mice but not in those that received splenocytes from IL-10-KO mice. Ragweed challenge resulted in exaggerated airway inflammation in IL-10-KO mice compared with wild-type mice, as determined by the level of eosinophils, lymphocytes, IL-4, IL-5, and serum levels of IgA, IgG1 and IgE. This enhanced inflammation was reversed by the administration of recombinant IL-10. Taken together, these data suggest that IL-10 reduces airway inflammation but promotes AHR following ragweed allergen challenge.

\section{Comments}


This work provides evidence that IL-10 expression plays a role in allergen-induced AHR. The mechanism by which IL-10 downregulates allergen-induced Th2 inflammation while increasing AHR may include one or more inflammatory mediators. Dissociation of the anti-inflammatory signal from the ability of IL-10 to increase AHR may hold some clinical applications.

\section{Methods}

Adoptive transfer, IL-10 knockout mice, allergen challenge, airway resistance and constriction management.

\section{Additional information}

\section{References}

1. Justice JP, Shibata Y, Sur S, Mustafa J, Fan M, Van Scott MR: IL-10 gene knockout attenuates allergen-induced airway hyperresponsiveness in C57BL/6 mice. Am J Physiol. 2001, 280: L363-L368.

This PDF file was created after publication. 